\title{
PSYCHE.
}

\section{THE NATURAL HISTORY OF ANOSIA PLEXIPPUS IN NEW ENGLAND.}

\author{
By SAMUEL HUBbARD SCUDDER, CAMBridge, MASS.
}

This butterfly passes the winter in the imago state. In southern latitudes, according to Edwards, who has given it closest attention, it appears early in the spring and lays eggs upon the milk. weed just out of the ground, beginning in West Virginia in the early part of May. The insect matures there very rapidly, and passes through several generations, according to Mr. Edwards at least three, and probably four, in the course of the season, the latest brood of the butterflies hibernating. Riley, who was the first to give a tolerably full life history of the insect, claimed that in Missouri it was doublebrooded, the broods appearing in the latter half of June and in October. In New England, however, what we can learn of the butterfly indicates a somewhat different history. Some years ago, in publishing an account of its history here, I claimed that the insect was only single-brooded, first coming out of hibernation at the end of June and early in July, laying eggs for a month or so, and the butterflies from these eggs hibernating. A great many points concerning its history both here and elsewhere have been brought out since then, and the facts as we know them at present may probably be interpreted somewhat in this way.

The butterflies, which are far more numerous in the late autumn than at any other time, seek winter quarters to hibernate, but with very rare exceptions, north of the natural division line of the Canadian and Alleghanian fau. nas, and even to a considerable distance to the south of this, possibly sometimes throughout the entire district of New England, every single specimen perishes. Now and then an old and battered female may be found in the month of May, but we have actually on record as far as I can discover but two or three instances of this, and one of these is not specific. A female much worn and faded was found May i 2 at Amherst by Professor Parker, and in another year the butterfly was found by Mr. W. D. Marsh on May 15 and May 21 at the same place; while Mr. Caulfield speaks in general terms of the appearance of butterflies in Montreal in May. In the 
extreme southern portions of New England and the neighboring districts, we have not infrequent appearances of hibernating butterflies early in May. But neither hibernators nor their progeny, in the preparatory stages - the only absolutely certain proof of an early brood, - are with possibly rare exceptions to be found in the northern half or more of New England either in May or early in June. The first occurrence of the insect there in any form is much later in the season, generally by the middle of June, occasionally by the very first, sometimes not until the very end of this month, when fine fresh butterflies make their appearance, at about the same time as, or a trifle later than, the advent a little further south of the first fresh brood of butterflies from eggs of the same season,-thus giving all the appearance throughout New England of an identical swarm of butterfties, varying in time from those found next the southern borders of New England only so much as would be expected from latitude.

This brood is in my opinion to be accounted for only on the supposition that they are colonists from the south which have flown to more northern districts from that impulse to wander which is one of the psychological characteristics of this butterfly. This hypothesis is further supported by the essentially tropical nature of the butterfly, which would prevent its establishing itself as a permanent resident rather than as an annual visitor of northern districts; by its well-known vast power of flight; as well as by its comparative history in the south. These butterflies begin in New England to lay their eggs usually in the first week in July, but occasionally as early as the middle of June. Dr. Harris records some caterpillars found on the 28 th of June which had reached the length of an inch on the $5^{\text {th }}$ of July, and I have found them in Shirley, Mass., of the length of six millimetres, therefore probably in the second stage, on the $22 \mathrm{~d}$ of June. These were unusually early caterpillars of the brood which had flown from the sout? and which sometimes makes its advent early in June. Both Mr. F. H. Sprague and myself have found them about Boston as early as the $2 \mathrm{~d}$ of this month in good condition, and single additional specimens were found in the same year by Mr. Sprague on the $9^{\text {th }}$ and $5^{\text {th }}$ of Jume. They never, however, become at all abundant before the first week in July, when the eggs are ordinarily laid. The eggs continue to be laid throughout this entire month without any interruption.

As regards the later history of this butterfly in the north, we are still somewhat in doubt. Mr. Edwards urges with great pertinacity that the behavior of the butterfly in the north is altogether parallel to its behavior in the south, but this would hardly seem as yet to be settled; at any rate the appearance of the latest fresh butterflies of the season may easily be accounted 
for on the supposition that they were produced from eggs laid by the older females of the first brood of colonists. For the observer will notice that eggs are laid by butterflies both in a fairly fresh condition and also by those which have been upon the wing a long time, and the closest observations I have been able to give through many summers both of butterflies seen in the act of depositing their eggs and of the contents of the ovaries of others, lead me strongly to the conviction that this butterfly requires more than a brief time for oviposition, the eggs maturing by degrees and not being fully laid until the butterfly has been upon the wing about an entire month. The examination of butterflies fresh from the chrysalis shows that the eggs are never entirely mature at this time, while on the other hand these butterflies retain their freshness of appearance for a longer time than usual after they have come from the chrysalis. That there is easily time for a second brood of butterflies from eggs laid by the progeny of the first colonists (basing our judgment upon the facts as given us by $\mathrm{Mr}$. Edwards in the south), there can be little doubt, but the proof of such a second brood has yet to be given. While, therefore, I am compelled by the facts that have been advanced since my former account of this species was published to modify my views in one respect, I am still inclined to think it in the main correct, viz., that this butterfly is normally single brooded throughout the larger part of New England; but that it requires an annual visitation of colonists from the south to exist at all, the hibernating butterflies perishing annually, almost to an individual.

Mr. Edwards entertains a different opinion regarding its life history in New England and does not believe that the butterflies which have hibernated perish to any such extent as I have presumed; and, because single instances of hibernating butterflies have been found in Massachusetts, he considers that "this settles the matter." But he fails to mention the fact that during the year i 887 when one observer found two of these hibernating butterflies in May at Amherst, this observer (Mr. Marsh), who was constantly on the watch for this butterfly, discovered but these two specimens in the season, while a number of Mr. Edwards' New England correspondents, whom he had similarly put upon a special search, were unable to find any; nor does he take note of the fact that Amherst, the only place in which these hibernating butterflies have yet been found in so northern a latitude as Massachusetts, is in the Connecticut valley, where the isotherms trend northward; and which is but a comparatively short distance north of those parts of southern Connecticut, in the valley of the same river, where it is not improbable that successfully hibernating butterflies may be found in all favorable years; nor is he perhaps aware that the valley of this river is one in which southern butterflies find their way far- 
ther north than at any other point in New England excepting in some instances along the sea-board.

My own collecting in New England, where this butterfly is much less common than further south, leads me to believe that it is far easier to obtain it by search for the caterpillar on the leaves of Asclepias than by capture upon the wing; and I should rather decide upon the presence of butterflies in any particular district by a search for plants of $A s$ clepias in suitable spots, than by watching for the butterflies; so that the failure year after year to find such larvae on young and tender plants in the very spots which are invariably chosen by the July butterflies whereon to deposit their eggs is to me very strong proof that the butterfly does not ordinarily exist in any form during the early months of the year in regions that I have searched. Regarding the later broods it may be added that the observations of $\mathrm{Mr}$. Marsh, who raised butterflies as late as the latter half of October and even in November, were made in part at least upon housed larvae and that at this late epoch of the year the transformations of the insect are very much slower than they are earlier in the season. Thus Mr. Marsh himself states that the pupal period in October is about three weeks, while in September it is only about a fortnight. In midsummer it is about ten days.

Mr. Edwards, accepting a suggestion of $\mathrm{Mr}$. Marsh, further urges that the failure to discover the hibernators in the spring is due to their rarity in the autumn and the latter from the fact that in New England the fields are often mowed for a second crop and that with the hay great quantities of milk-weed are cut down. But aside from the fact that the larger part of the milk-weeds inhabited by the caterpillars is found by the side of roads and lanes and in close vicinity to shrubbery, where it is not disturbed by the scythe, there is a single fact which renders this argument absolutely useless, viz., that the imago is far more abundant late in the season than at any other time in the year, sometimes swarming to an excessive extent and found in New England in the same abundance that it is so often found in the west. Yet so far as I have been able to find from inquiries (unfortunately not made at the time), in no instance have hibernators been seen in years immediately succeeding autumns which have witnessed a vast profusion of butterflies, nor have autumns of great abundance been followed by springs of plenty. 

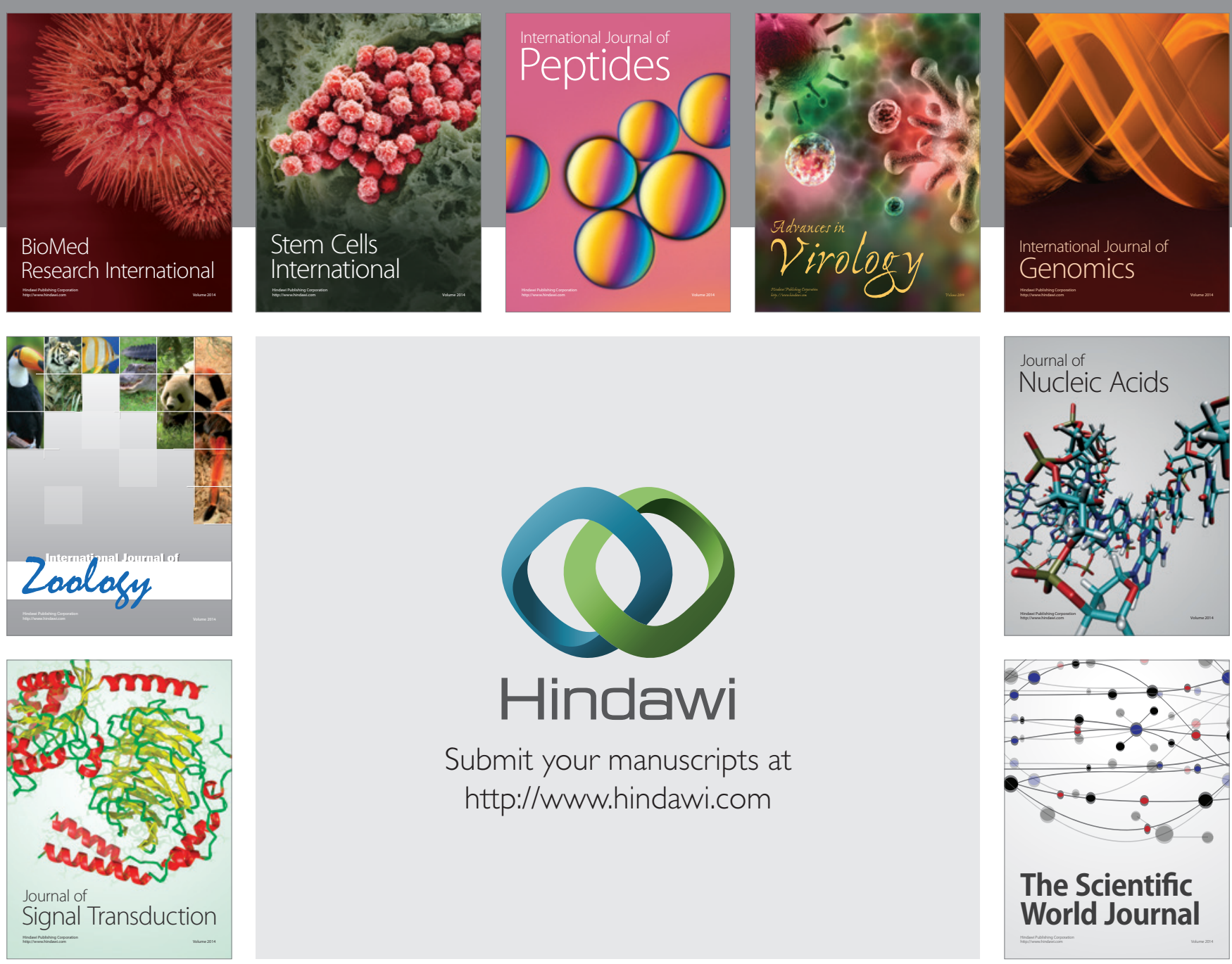

Submit your manuscripts at

http://www.hindawi.com
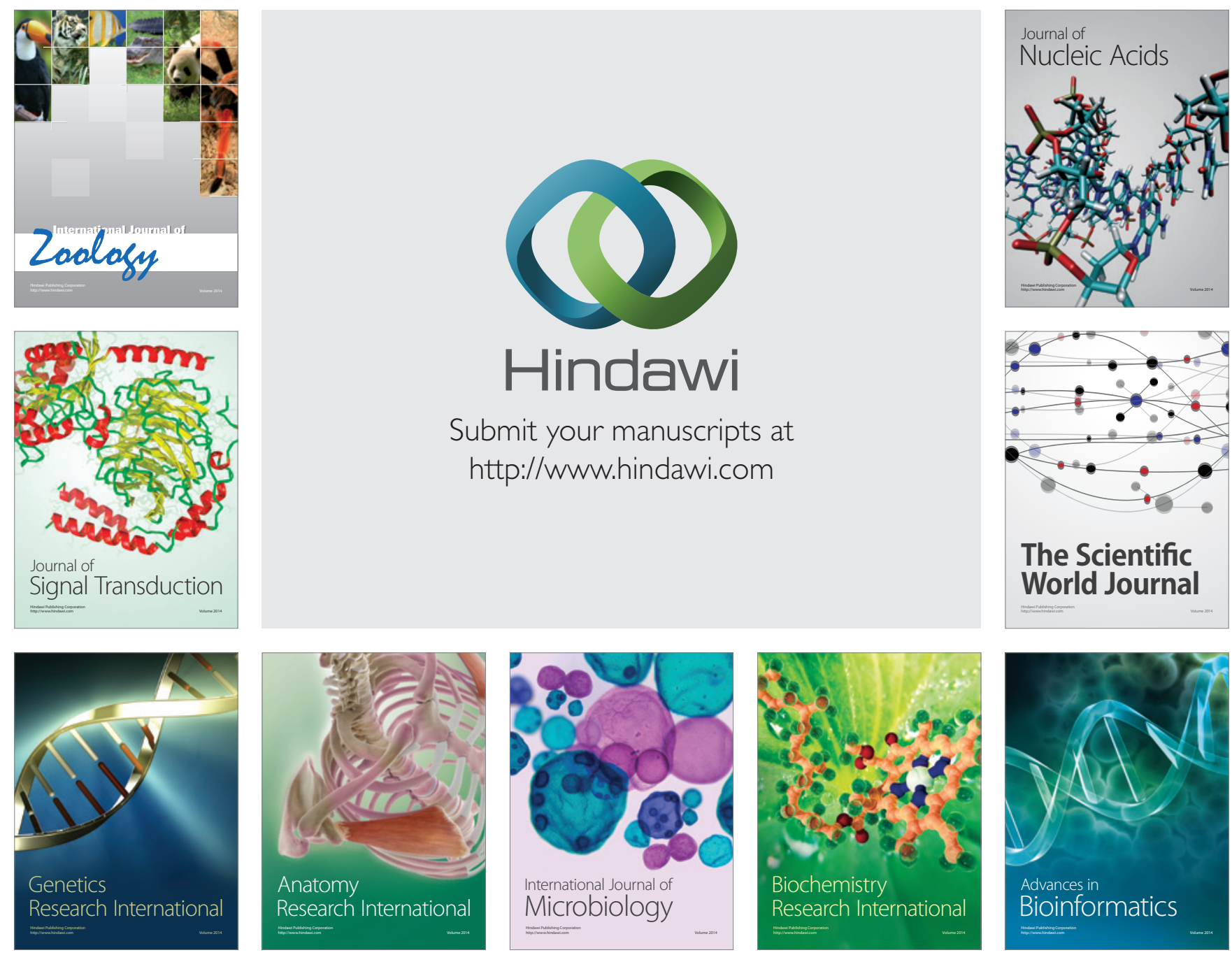

The Scientific World Journal
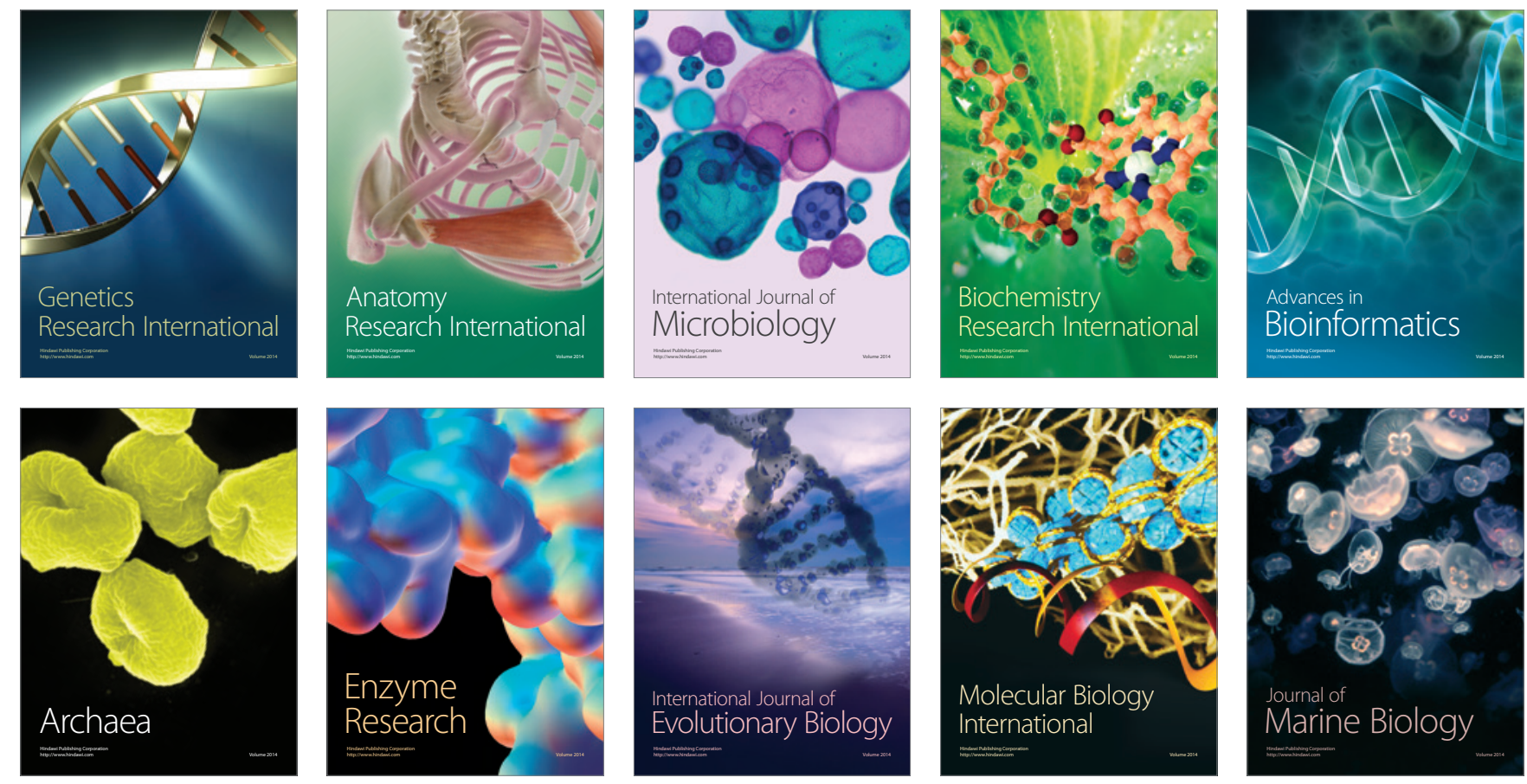